\title{
Women's Participation in Agricultural Employment with Special Reference to Uttar Pradesh and Uttarakhand in India
}

\author{
Neha Vishwakarma \\ Department of Economics, Banaras Hindu University, Varanasi, Uttar Pradesh-221005, India \\ Corresponding author: nehavishwakarma566@gmail.com
}

\begin{abstract}
Role of women employment is a vital indicator of development showing the proportion of the working population in Indian economy. In spite of high economic growth and significant upsurge in gender equality there is gender gap in economic participation in India. This research paper shows an analysis of women's participation in agricultural employment with special reference to Uttar Pradesh and Uttarakhand in India. Although the female population is higher in U.P. but female work participation is higher in Uttarakhand. The growth of female work participation almost remains constant. The level and nature of female labour force during the study period is not so good.
\end{abstract}

Keywords: Female worker, Agricultural employment, Agricultural proprietary establishments, Female work participation ratio, Uttar Pradesh and Uttrarakhand

Agriculture sector developed and emerged with the infusion of science and technology but it has not been accepted women as key labour yet. According to the Census of India, a worker is defined as a person whose main activity is participation either physical or mental in nature in any economically productive activity. Work involved is not only actual work but also effective supervision and direction of work. Unpaid work on farm or in family enterprise is also included.

Women in agricultural labour force are considered such as farmers on their own farms, as unpaid workers on family farms and as paid or unpaid labourers on others farms and agricultural enterprises. Their involvement in crop and livestock production as well as fishing farming on subsistence and commercial are also included in agricultural labour force. Women who are working or looking for work in formal or informal jobs and in paid or unpaid employment in agriculture are included in agricultural labour force. Self-employed women as well as women working on family farms are also considered as agricultural labour force. Domestic chores such as fetching water and firewood, preparing food and caring for children and other family members are not defined as agricultural labour force. (FAO 2010)

\section{REVIEW OF LITERATURE}

Rao et al. (2016) examined the trends and pattern of women's employment in India using secondary data for the time period from Census 1981 to Census 2011. All states and union territories of India as population and seven states from high per capita income states and seven states from low per capita income states were selected as sample states for the study. Result indicated that high variation in percentage of female workers to total worker ratio across the states.

Ghosh and Ghosh (2014) analyzed the women participation in agriculture across diverse Indian states. He found that, women participation in agriculture was increased but discrimination of wages and in working status still triumphs for women labour. The World Development Report (2012) stressed that gender equality and empowering women as economically, socially, and politically can improve level of their decision making power. 
The State of Food and Agriculture (2011) stated to free women's time for more productive activities and to facilitate women's participation in flexible, efficient, and fair rural labour markets. There is an urgent need to fill the gender gap.

World development Report (2008) identified the changing roles and growing contributions of women in agriculture and rural livelihoods and also identified changing gender role and division of labour in demography and household structure as a result of migration.

Shiva (1991) discussed active involvement of women in agricultural activities in rural economy in India however there is variation in extent and nature of their participation in agro production system. The forms of female contribution in agriculture production differ with the landowning status of farm households.

Chopra (1979) studied the variations in the incidence of cultivators, agricultural labourers and female workers in three agro-climatic zones (i.e., wheat, millet and rice regions) over three census years-1951, 1961, and 1971. She found that the cropping pattern (i.e., proportion of labour intensive crops) and the sex-ratio were significant variables in explaining the incidence of female cultivators and agricultural labourer.

\section{Methodology}

The study is mainly based on secondary data obtained from the Government of India reports. The main sources of the data are Statistical Profile on Women Labour, Labour Bureau, Government of India and participation in economy, men and women in India 2016, Ministry of Statistics and Programme Implementation, Government of India. The time period we consider for our study is from 2001 to 2011 census years. The study covered 2 census rounds on women statistics from 2001 to 2011. Statistical Profile on Women Labour covered 2001-2011 years of all India as well as selected states such as Uttar Pradesh and Uttarakhand.

The overall objective of this paper is to analyze the women employment scenario in Indian agriculture sector. The specific objectives of the study are:

(a) To analyze the level and nature of female labour force during the study period; (b) To examine the differences regarding female work participation between the Uttar Pradesh and Uttarakhand.

(c) To measure the extent of female work participation growth during the study period.

\section{DISCUSSION}

India is male dominated country which is also seen by Establishments and employment in agricultural proprietary. The percentage of male is higher in both establishments and workers in agriculture whereas the percentage of female participation shows the larger gender differences in economic activity in India.



Fig. 1

Source: Women $\mathcal{E}$ Men in India - 2016, Government of India

The Table 1 shows that although the total female population is higher in Uttar Pradesh than the Uttarakhand but the percentage of total Female worker is higher in Uttarakhand than the U.P. in both the years 2001 and 2011.

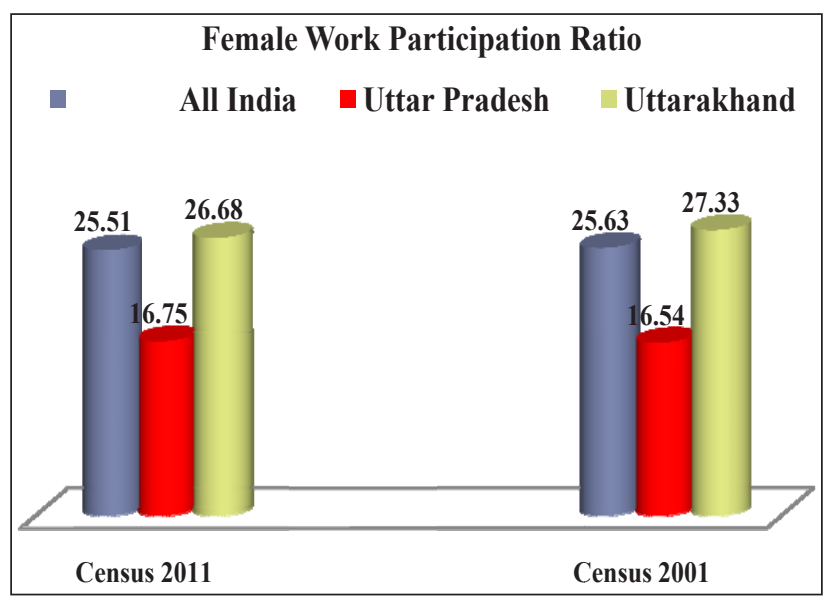

Fig. 2 
Table 1: Distribution of female workers in Uttar Pradesh and Uttarakhand

\begin{tabular}{cccccccccc}
\hline & \multicolumn{2}{c}{ All India } & \multicolumn{3}{c}{ Uttar Pradesh } & \multicolumn{3}{c}{ Uttarakhand } \\
\hline $\begin{array}{c}\text { Census } \\
\text { year }\end{array}$ & $\begin{array}{c}\text { Female } \\
\text { worker }\end{array}$ & Total worker & $\%$ & $\begin{array}{c}\text { Female } \\
\text { worker }\end{array}$ & Total worker & $\%$ & $\begin{array}{c}\text { Female } \\
\text { worker }\end{array}$ & $\begin{array}{c}\text { Total } \\
\text { worker }\end{array}$ & $\%$ \\
\hline 2001 & 127220248 & 402234724 & 31.63 & 13002266 & 53983824 & 24.09 & 1137859 & 3134036 & 36.31 \\
2011 & 149877381 & 481743311 & 31.11 & 15967953 & 65814715 & 24.26 & 1320354 & 3872275 & 34.1 \\
\hline
\end{tabular}

Source: Statistical profile on Women labour, Government of India.

Table 2: Female's participation in agricultural employment (All India)

\begin{tabular}{ccccc}
\hline All India & \multicolumn{4}{c}{ Percentage of Total Female workers } \\
\hline Year & Total female worker & $\begin{array}{c}\text { Female cultivators } \\
\mathbf{( \% )}\end{array}$ & $\begin{array}{c}\text { Female Agricultural } \\
\text { Labourers (\%) }\end{array}$ & $\begin{array}{c}\text { Female Agricultural } \\
\text { Worker }(\mathbf{\%})\end{array}$ \\
\hline Census 2001 & $12,72,20,248$ & 32.93 & 38.87 & 71.8 \\
Census 2011 & $14,98,77,381$ & 24.0 & 55.21 & 79.22 \\
\hline
\end{tabular}

Source: Statistical profile on Women labour, Government of India.

According to census of India, female work participation rate is defined as the percentage of total female workers to total female population. As we see Fig. 2 in census 2001 the FWP ratio for all India is 25.63 per cent which declined by 0.12 percent in 2011 shows that escalating the gender gap in work participation in Indian economy. Although comparing the two states of India i.e. Uttar Pradesh and Uttarakhand, it is observed that FWP is higher in Uttarakhnad than U.P in both the census years 2001 and 2011. The FWP of Uttarakhand is more than $9.33 \%$ and $10.79 \%$ in comparison to U.P with respective years but FWP has declined by $0.65 \%$ and increased by $0.21 \%$ in U.P.

Agricultural laborer is defined as a person who worked on another person's land for wages in money, kind or share of crop. A person was considered working as cultivator if he or she was engaged either as employer, single worker or family worker in the cultivation of land owned or held from Government or from private person or institution for payment in money, or in kind or on the basis of sharing of crops. Cultivation also included supervision or direction of cultivation. Female agricultural worker is the sum of female cultivator and female agricultural laborer.

The Table 2 indicates that Percentage of female cultivators to female worker declined by 8.93 even if female agricultural worker is increased by 7.42 percent due to increment in female agricultural laborers by 16.34 percent in census 2011 .
In Uttar Pradesh, it is observed that the female agricultural worker is decreased by 15.06 percent with decline in both female cultivators and agricultural laborers by 13.84 percent and 1.22 percent respectively in 2011 census year.

In Uttarakhand, it is found that although the female agricultural worker is decreased by 11.08 percent with decline in female cultivator's percentage by 13.84 but female agricultural laborers has increased by 2.76 percent in census 2011 .

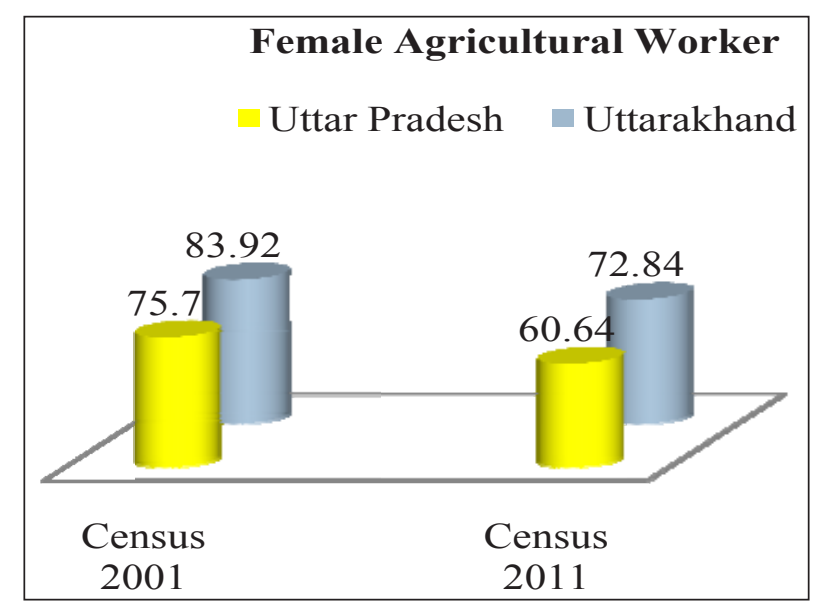

Fig. 3

Above fig. 3 comparing both the states it is stated that percentage of female agricultural workers to total female worker is less in Uttar Pradesh in both the census year i.e. 2001 and 2011. Although it is seen that the Female agricultural worker is decreased in both the states but the rate of decline is more in U.P by 3.98 percent. Declining rate of 
Table 3: Female's participation in agricultural employment (Uttar Pradesh)

\begin{tabular}{ccccc}
\hline \multicolumn{2}{c}{ Uttar Pradesh } & \multicolumn{3}{c}{ Percentage to Total Female workers } \\
\hline Year & Total female worker & $\begin{array}{c}\text { Female Cultivators } \\
\mathbf{( \% )}\end{array}$ & $\begin{array}{c}\text { Female Agricultural Labourers } \\
\mathbf{( \% )}\end{array}$ & $\begin{array}{c}\text { Female Agricultural } \\
\text { Worker (\%) }\end{array}$ \\
\hline Census 2001 & $1,30,02,266$ & 36.05 & 39.65 & 75.7 \\
Census 2011 & $1,59,67,953$ & 22.21 & 38.43 & 60.64 \\
\hline
\end{tabular}

Source: Statistical profile on Women labour, Government of India.

Table 4: Female's work participation in agricultural employment (Uttarakhand)

\begin{tabular}{ccccc}
\hline \multicolumn{2}{c}{ Uttarakhand } & \multicolumn{3}{c}{ Percentage to Total Female workers } \\
\hline Year & Total female worker & Female Cultivators (\%) & $\begin{array}{c}\text { Female Agricultural Labourers } \\
\text { (\%) }\end{array}$ & $\begin{array}{c}\text { Female Agricultural } \\
\text { Worker (\%) }\end{array}$ \\
\hline Census 2001 & $11,37,859$ & 77.84 & 6.08 & 83.92 \\
Census 2011 & $13,20,354$ & 64.00 & 8.84 & 72.84 \\
\hline
\end{tabular}

Source: Statistical profile on Women labour, Government of India.

Female cultivator's percentage is same i.e. $13.84 \%$ but female agricultural laborers has increased in Uttarakhand but it is decline in Uttar Pradesh in census year 2011.

\section{CONCLUSION}

It is concluded that although the female population is higher in U.P. but female work participation is higher in Uttarakhand. The growth of female work participation almost remains constant. The level and nature of female labour force during the study period is poor. There are several causes one of them may be female labour force in Indian states still faces the oppressive status of being majorly responsible for family, children and household maintenance.

\section{REFERENCES}

Chopra, K. 1979. Female Work Participation in the Three crop Regions of India an Inter-Regional Study of Rural India between 1951, 1961 and 1971. Programme on Women Studies, ICSSR.

F.A.O.2010. Gender dimensions of agricultural and rural employment: Differentiated pathways out of poverty Status, trends and gaps. The Food and Agricultural Organization of the United Nations. The International Fund for Agricultural Development and the International Labour Office. Rome.
F.A.O.2011. Women in agriculture: Closing the gender gap for development. The Food and Agricultural Organization of the United Nations. The International Fund for Agricultural Development and the International Labour Office, Rome.

GOI. 2012. Statistical profile on women 2012-13. Labour bureau, Ministry of labour \& employment, Government of India. New Delhi, India.

GOI. 2016. Men and Women in India 2016, Ministry of Statistics and Programme Implementation, Government of India. New Delhi, India.

Ghosh, M.M. and Ghosh, A. 2014. Analysis of Women Participation in Indian Agriculture. Journal of Humanities and Social Science, 19(5): 01-06.

Rao, P.M., Kumar, Y.A., Kataih, CH.B. and Naik, J.N. 2016. Trends in women employment in India during census 1981 to 2011. Economic Affairs, 61(3): 561-573.

Shiva, V. 1991. Most farmers in India are women. Food and Agriculture Organization of the United Nations, Rome.

World Bank. 2008. Agriculture for Development. World Development Report 2008, Washington DC.

World Bank. 2012. Gender Equality and Development. World Development Report 2012. Washington, DC. 